\title{
The Social-environmental Risk Factor for Conjunctivitis
}

\author{
Lilis Suryani ${ }^{1 *} \mathbb{D}$, Yunani Setyandriana ${ }^{2}$, Nur Shani Meida ${ }^{2}$ \\ ${ }^{1}$ Department of Microbiology, Medical Science and Health Faculty, Universitas Muhammadiyah, Yogyakarta, Indonesia; \\ ${ }^{2}$ Department of Eye, Medical Science and Health Faculty, Universitas Muhammadiyah, Yogyakarta, Indonesia
}

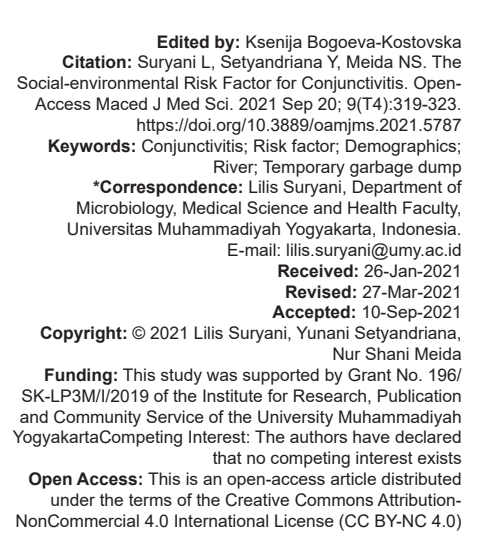

Introduction

The most common type of eye disease worldwide is conjunctivitis and $36 \%$ of cases occur in adult [1]. In Pakistan, as much as $19.2 \%$, the prevalence of allergic conjunctivitis occurs in boys [2]. The incidence of conjunctivitis in Indonesia reaches $73 \%$ of people with eye disorders. Acute conjunctivitis is caused by infection and non-infection, mostly found in primary care and ophthalmology hospitals [3]. Bacteria, fungi, viruses, parasites, and allergies are some of the causes of conjunctivitis. [4]. Bacterial conjunctivitis is more common in children. About $15-40 \%$ of the incidence of conjunctivitis is due to allergies [5]. In subtropical countries, the incidence of allergic conjunctivitis tends to increase in spring [6]. In Mongolia, cases of conjunctivitis are more common in urban areas than in rural areas [7]. In the United States, viral conjunctivitis infects many adults and occurs most frequently in summer [8], [9], [10], [11].

Conjunctivitis is one of the top 10 conditions in outpatient hospital units in Indonesia [12]. Conjunctivitis due to bacterial infection can be transmitted from one eye to another and from the patient to another, either through direct contact or through objects in touch with the infected eye [13]. Behaviors that are potential risk factors for conjunctivitis include washing hands, using towels, pillow/pillowcases, and handkerchiefs together. There are some symptoms of conjunctivitis. Symptoms that arise in acute bacterial conjunctivitis include redness of the eyes, feeling stuck, sore, discharge, when waking up, the eyelids are often sticky and challenging to open [14]. It can lead to acute conjunctivitis.

Acute conjunctivitis lasts 10-14 days; if appropriately treated, it will heal in 1-3 days. The complication will happen if it does not treat properly [15]. Apart from infection, conjunctivitis can also be caused by allergies. An inflammatory reaction in the conjunctiva that is mediated by a type 1 hypersensitivity reaction can cause allergic conjunctivitis [16], [17]. The tear film, eyelids, cornea, and conjunctiva are the parts of the eye that is affected by allergic conjunctivitis. The signs of conjunctivitis vary widely, influenced by genetics, environment, microorganisms, and immune status of the person [18]. Allergic conjunctivitis affects children in Ankara, Turkey, by $4.6 \%$. Bacterial conjunctivitis affects adults by $36 \%$ in the United States. In Pakistan, $19.2 \%$ of boys aged 5-19 have allergic conjunctivitis. In Mongolia, more cases of allergic conjunctivitis are found in cities than in rural areas [19]. In the subtropics, vernal allergic conjunctivitis is expected in the spring. 
In areas with a high population density, there is a lot of phlyctenule conjunctivitis in children. In regions with geographic conditions that tend to be dry, hot, and dusty, trachoma cases are found, for example, in North India, North Africa, and West Africa [20]. Bacterial conjunctivitis affects a lot of children. The infection symptoms are sometimes systemic, such as fever, sore throat, otitis media, and diarrhea. In Medan, $78 \%$ prevalence of conjunctivitis occurred in people aged less than 30 years. An environment with a lack of sanitation or environmental hygiene is one of the risk factors that help spread quickly. The primary preventive measure in conjunctivitis is to avoid risk factors [21]

There has not been too much research on conjunctivitis risk factors in Indonesia. The study of demographic and behavioral risk factors associated with conjunctivitis has been carried out frequently in several countries. Thus, this research is important to do to identify the social-environmental risk factors that affect conjunctivitis in Yogyakarta. We hoped this study gave some information about risk factors associated with conjunctivitis.

\section{Methods}

The study design was an analytic observational study with a case-control design. The period study was conducted from January to December 2019. The population study in both cases and control was all patients who were treated at the Eye Clinic of PKU Muhammadiyah Gamping Hospital and private hospital in Yogyakarta, based on a diagnosis made by an ophthalmologist. The case population was all patients who were declared conjunctivitis and the control population was all patients who were declared nonconjunctivitis. This study used a sample of 104 case respondents and 100 respondents as controls. Sampling was taken by total sampling, all patients treated at the Eye Clinic of PKU Muhammadiyah Gamping Hospital and private hospital Yogyakarta in 2019. Determination of case and control respondents was carried out by standard examinations that are usually carried out to determine the criteria for conjunctivitis in the eye clinic. Patients who became respondents were asked for consent by signing the informed consent.

Collecting risk factor data which include the characteristics and social-environmental risk factor of respondents, both cases and controls, were obtained through questionnaires. A set of checklists are made to record the respondents. The checklist contains demographic data, the distance between the house and the river, the distance between the house and the temporary garbage dump, being infected by a close friend, and the house windows are always open every day. The Chi-square test was done using SPSS version 21.0 , to calculate the odds ratio with a $95 \%$ confidence interval value $(a=0.05)$.

\section{Results}

The categories of respondents based on gender, age, and type of occupation are presented in Table 1. The respondents of conjunctivitis cases aged $20-40$ years were $44 \%$ and control respondents were over 40 years old $52 \%$. Most cases and control respondents work indoors. The sex between cases and controls was mostly women. Of the three respondents' characteristics, age was a risk factor for the incidence of conjunctivitis in Yogyakarta $(p<0.05)$.

Table 1: Frequency distribution of case and control respondents based on age, type of occupation, and gender

\begin{tabular}{|c|c|c|c|c|}
\hline Demography & Cases $(n=104)(\%)$ & Control $(n=100)(\%)$ & $p$-value & Cl 95\% \\
\hline \multicolumn{5}{|l|}{ Age (year) } \\
\hline$<20$ & $34(33)$ & $15(15)$ & $0.000^{*}$ & $2.03-2.24$ \\
\hline $20-40$ & $46(44)$ & $33(33)$ & & \\
\hline$>40$ & $24(23)$ & $52(52)$ & & \\
\hline \multicolumn{5}{|l|}{ Occupation } \\
\hline Indoor & $74(71)$ & $74(74)$ & 0.649 & $1.21-1.34$ \\
\hline Outdoor & $30(29)$ & $26(26)$ & & \\
\hline \multicolumn{5}{|l|}{ Gender } \\
\hline Men & $46(46)$ & $39(39)$ & 0.449 & $1.35-1.48$ \\
\hline & $58(56)$ & $61(61)$ & & \\
\hline \multicolumn{5}{|c|}{${ }^{*}$ Significant $p<5 \%$} \\
\hline
\end{tabular}
factors studied, as listed in Table 2. The majority of respondents live far from rivers and temporary garbage dumps, and their windows are always open every day. Just $35 \%$ of patients with conjunctivitis are infected by a close friend. The social-environmental risk factors that influenced the incidence of conjunctivitis in Yogyakarta include: The distance between the house and the river, the distance between the house and the temporary garbage dump, being infected by a close friend, and the house windows are always open every day.

Table 2: Comparison of social-environmental risk factors for case and control groups in the incidence of conjunctivitis

\begin{tabular}{|c|c|c|c|c|}
\hline Social-environment variable & $\begin{array}{l}\text { Cases }(n=104) \\
(\%)\end{array}$ & $\begin{array}{l}\text { Control } \\
(n=100) \\
(\%)\end{array}$ & $p$-value & $\mathrm{Cl} 95 \%$ \\
\hline \multicolumn{5}{|c|}{ Distance between house and river } \\
\hline$>250 \mathrm{~m}$ & $82(79)$ & $97(97)$ & $0.000^{*}$ & $1.08-1.17$ \\
\hline$<250 \mathrm{~m}$ & $22(29)$ & $3(3 \%)$ & & \\
\hline \multicolumn{5}{|c|}{$\begin{array}{l}\text { Distance between the house and the } \\
\text { temporary garbage dump }\end{array}$} \\
\hline$>250 \mathrm{~m}$ & $90(87)$ & $97(97)$ & $0.007^{*}$ & $1.05-1.12$ \\
\hline$<250 \mathrm{~m}$ & $14(13)$ & $3(3)$ & & \\
\hline \multicolumn{5}{|l|}{ Being infected by a close friend } \\
\hline Yes & $36(35)$ & 0 & $0.000^{*}$ & $1.77-1.87$ \\
\hline No & $64(65)$ & $100(100)$ & & \\
\hline \multicolumn{5}{|l|}{ The window always opens daily } \\
\hline Yes & $82(79)$ & $95(95)$ & $0.001^{*}$ & $1.09-1.18$ \\
\hline No & $22(21)$ & $5(5)$ & & \\
\hline
\end{tabular}

\section{Discussion}

This study shows that age is a risk factor for conjunctivitis in Yogyakarta, while sex and occupation 
have no relationship with the incidence of conjunctivitis. It is in line with the conjunctivitis research in the other place in Indonesia [22]. The findings of this study differ from those of Taiwan. In Taiwan, women were at a higher risk than men [23]. In the United States, 36\% of conjunctivitis cases occur in adults [1]. In Pakistan, as much as $19.2 \%$, the prevalence of allergic conjunctivitis occurs in boys [2]. Bacterial conjunctivitis affects adults by $36 \%$ in the United States. In Pakistan, $19.2 \%$ of boys aged 5-19 have allergic conjunctivitis. Several species of bacteria cause conjunctivitis, from the Gram-positive and -negative groups. Bacterial infectious conjunctivitis is transmitted from one eye to the other eye and another person, through direct contact and objects in contact with the infected eye [13].

About $35 \%$ of people with conjunctivitis get it from a close friend. Conjunctivitis transmission occurs if someone comes in direct contact with a person with conjunctivitis. This condition is supported by the fact that most respondents have activities in the room. The most common causes of conjunctivitis in the world are bacteria and fungi [4]. The bacteria that cause conjunctivitis are several species, among which are Haemophilus influenzae, Moraxella catarrhalis, Staphylococcus epidermidis, Streptococcus viridans, Staphylococcus aureus, Streptococcus pneumoniae, and Gram-negative bacteria [24], [25], [26]. S. aureus is Gram-positive cocci bacteria that are mostly found in conjunctivitis cases [16]. The microbe that causes conjunctivitis influences the spread of conjunctivitis infectious. There are many mechanisms of conjunctivitis transmission, including contact transmission, droplet transmission, water transmission, and vector transmission. S. aureus, S. pneumoniae, $H$. influenzae, and Neisseria gonorrhoeae cause acute and hyperacute conjunctivitis [27], [28], [29], [30]. Adenoviruses of the subgenus D, coxsackieviruses of the Picornaviridae family, and herpes (HSV1) are the most common causes of acute hemorrhagic conjunctivitis [27].

Touching the eye with unclean hands was one way to spread bacterial conjunctivitis. The eye has natural defenses in the form of normal flora, immunoglobulins, and enzymes. The normal flora in the eye includes Streptococcus, Staphylococcus, and Corynebacterium bacteria. If the body's immunity decreases, the number of normal flora will increase and infection will occur. Furthermore, bacteremia and the organs around the infected eye can spread to the eye. Picornavirus, adenovirus, Herpes simplex, Poxvirus, and Varicella zoster are some virus that causes conjunctivitis. Viruses are transmitted through respiratory droplets and contact with objects contaminated with viruses. Allergic conjunctivitis is caused by many allergens in the environment, such as pollen, animal hair, and mold spores. Atopic conjunctivitis attacks patients who have a history of atopic dermatitis.

Study on social-environmental risk factors for conjunctivitis has not been widely used. In this study, the social-environmental risk factors that influence the incidence of conjunctivitis are the distance between the house from the river and a temporary garbage dump. Houses close to rivers and temporary garbage dumps usually have poor sanitation. River water can pollute well water which is usually used to meet the daily needs of the people of Yogyakarta. The existence of temporary garbage dumps that are very close to residential areas also contributes to creating a dirty environment. About $29 \%$ of conjunctivitis sufferers live near rivers. In Yogyakarta, four rivers are flowing in the middle of residential areas: Gajah Wong, Code, Winongo, and Manunggal. During the rainy season, river water overflows and inundates residential areas close to the river. Flood water pollutes the well; consequently, the well water is contaminated with various kinds of pathogenic microorganisms. It is necessary to analyze the microbes isolated from well water to ensure the source of infection is from the patient's well water or other sources. The findings were then compared between microbial isolates from well water and conjunctivitis isolates. The metagenomic approach is used to study the microbes that cause conjunctivitis. Microorganisms that are difficult to identify with conventional culture methods can be detected using metagenomics [31], [32]. In ophthalmology, metagenomics has been used to detect infectious pathogens of proliferative disorders, classify pathogens from infectious keratitis [33], and analyze vitreous samples of endophthalmitis after cataract surgery [34]. The downstream bioinformatics data show detailed findings based on metagenomics data [32].

The limitations of this study include the study did not examine the microbes that cause conjunctivitis. Hence, the cause of conjunctivitis in patients is not known with certainty, and the determination of the distance between the house to the river and the temporary garbage dumps was only based on interviews with respondents.

\section{Conclusion}

It was observed that age was a risk factor for conjunctivitis in Yogyakarta. Besides that, the social-environment as risk factor for conjunctivitis in Yogyakarta was the distance between the house and the river, the distance between the house and the temporary garbage dump, being infected by a close friend, and the window always opens daily. This study proves the recommendations that the government needs to rearrange the temporary landfill places and regulations for disposing of garbage to the temporary landfills. People who live near rivers are more vigilant about personal hygiene to prevent conjunctivitis infection. 


\section{References}

1. Udeh BL, Schneider JE, Ohsfelds RL. Cost effectiveness of a point-of-care test for Adenoviral conjunctivitis. Am J Med Sci. 2008;336(3):254-64.

PMid:18794621

2. Baig R, Ali AW, Ali T, Ali A, Shah MN, Sarfaraz A, Ahmad K. Prevalence of allergic conjunctivitis in school children of Karachi. J Pak Med Assoc. 2010;60(5):e371-3. PMid:20527610

3. Segal KL, Lai EC, Starr CE. Management of acute conjunctivitis. Curr Ophthalmol Rep. 2014;2:116-23. Available from: https:// www.link.springer.com/article. [Last accessed on 2019 Nov 15]. https://doi.org/10.1007/s40135-014-0046-4

4. Azari AA, Barney NP. Conjunctivitis: A systematic review of diagnosis and treatment. JAMA. 2013;310(16):1721-9. https:// doi.org/10.1001/jama.2013.280318

PMid:24150468

5. Moura FE, Ribeiro DC, Gurgel N, da Silva Mendes AC, Tavares FN, Timóteo $\mathrm{CN}$, et al. Acute haemorrhagic conjunctivitis outbreak in the city of Fortaleza, Northeast Brazil. Br J Ophthalmol. 2006;90(9):1091-3. https://doi.org/10.1136/ bjo.2006.098822

PMid:16809381

6. Wright HR, Turner A, Taylor HR. Trachoma and poverty: Unnecessary blindness further disadvantages the poorest people in the poorest countries. Clin Exp Optom. 2007;90(6):4228. https://doi.org/10.1111/j.1444-0938.2007.00218.x PMid:17958564

7. Tarabishy $A B$, Jeng $B H$. Bacterial conjunctivitis: A review for internists. Cleve Clin J Med. 2008;75(7):507-12.

PMid:18646586

8. Hovding G. Acute bacterial conjunctivitis. Acta Ophthalmol 2008;86(1):422-8.

9. Sheikh A, Hurwitz B. Topical antibiotics for acute bacterial conjunctivitis: Cochrane systematic review and meta-analysis update. Br J Gen Pract. 2005;55(521):962-4. PMid: 16378567

10. Everitt HA, Little PS, Smith PW. A randomised controlled trial of management strategies for acute infective conjunctivitis in general practice. BMJ. 2006;333(7563):321. https://doi. org/10.1136/bmj.38891.551088.7c

PMid: 16847013

11. Rietveld RP, ter Riet G, Bindels PJ, Bink D, Sloos JH, van Weert HC. The treatment of acute infectious conjunctivitis with fusidic acid: A randomised controlled trial. $\mathrm{Br} \mathrm{J}$ Gen Pract. 2005;55(521):924-30. https://doi.org/10.1007/bf03085370 PMid:16378561

12. Wald ER, Greenberg D, Hoberman A. Short term oral cefixime therapy for treatment of bacterial conjunctivitis. Pediatr Infect Dis J. 2001;20(21):1039-42. https://doi. org/10.1097/00006454-200111000-00007 PMid:11734708

13. Cronau H, Kankanala RR, Mauger T. Diagnosis and management of red eye in primary care. Am Fam Physician. 2010;81(2):137-44. PMid:20082509

14. Kanski JJ, Bowling B. Clinical Ophthalmology; a Systemic Approach. $7^{\text {th }}$ ed. New York: Elsevier, Saunders; 2011.

15. Gogate P, Gilbert C, Zin A. Severe visual Impairment and blindness in infants: Causes and opportunities for control. Middle East Afr J Ophthalmol. 2011;18(2):109-14. https://doi. org/10.4103/0974-9233.80698

\section{PMid:21731320}

16. MashigeKP.Ocularallergy. HealthSAGesondheid.2017;22:112-22. Available from: http://www.sciencedirect.com/science/article/pii/ S1025984816300217. [Last accessed on 2021 Mar 15]. https:// doi.org/10.1016/j.hsag.2016.07.001

17. Mishra GP, Tamboli V, Jwala J, Mitra AK. Recent patents and emerging therapeutics in the treatment of allergic conjunctivitis. Recent Pat Inflamm Allergy Drug Discov. 2011;5(1):26-36. https://doi.org/10.2174/187221311794474883

PMid:21171952

18. Pelikan Z. Cytokines in tears during the secondary keratoconjunctival responses induced by allergic reaction in the nasal mucosa. Ophthalmic Res. 2014;52(1):32-42. https://doi. org/10.1159/000358200

PMid:24903557

19. Sthapit PR, Tuladhar NR, Marasini S, Khoju U, Thapa G. Bacterial conjunctivitis and of antibiotics in Dhulikhel HospitalKathmandu University Hospital. Kathmandu Univ Med J (KUMJ). 2011;9(34):69-72. https://doi.org/10.3126/kumj.v9i2.6292 PMid:22610873

20. Iwalokun BA, Oluwadun A, Akinsinde KA, Niemogha MT, Nwaokorie FO. Bacteriologic and plasmid analysis of etiologic agents of conjunctivitis in Lagos, Nigeria. J Ophthalmic Inflamm Infect. 2011;1(3):95-103. https://doi.org/10.1007/ s12348-011-0024-z PMid:21484175

21. Abdurrauf M. Memutus rantai penularan konjungtivitis bakteri akut. (Breaking the chain of acute bacterial conjunctivitis transmission). Idea Nurs J. 2016;7(2):1-4. Available from: http://www.jurnal. unsyiah.ac.id/inj/article/view/6447. [Lastaccessed on2018Nov14].

22. Wahyuni T. Faktor risiko yang berhubungan dengan kejadian konjungtivitis pada pekerja pengelasan di Kecamatan Cilacap Tengah Kabupaten Cilacap. (The risk factors affecting conjunctivitis in welding workers in Cilacap, Jawa Tengah, Cilacap Regency). J Kesehatan Masyarakat. 2013;2(1):1-9. Available from: http://www.ejournals1.undip.ac.id/index.php/ jkm. [Last accessed on 2018 Nov 14]. https://doi.org/10.14710/ marj.v2i3.4211

23. Chiang CC, Liao CC, Chen PC, Tsai YY, Wang YC. Population study on chronic and acute conjunctivitis associated with ambient environment in urban and rural areas. J Expo Sci Environ Epidemiol. 2012;22(5):533-8. https://doi.org/10.1038/ jes.2012.37

PMid:22714096

24. Zuppa AB, D'Andrea V, Catenazzi P, Scorrano A, Romagnoli C. Ophthalmia neonatorum: What kind of prophylaxis? J Matern Fetal Neonatal Medi. 2011;24(6):769-73. https://doi.org/10.310 9/14767058.2010.531326

PMid:21534852

25. Okesola AO, Salako, AO. Microbiological profile of bacterial conjunctivitis in Ibadan, Nigeria. Ann lb Postgrad Med. 2010;8(1):20-4. https://doi.org/10.4314/aipm.v8i1.63953 PMid:25161470

26. Asbell PA, Sahm DF, Shaw M, Draghi DC, Brown NP. Increasing prevalence of methicillin resistance in serious ocular infections caused by Staphylococcus aureus in the United States: 2000 to 2005. J Cataract Refract Surg. 2008;34(5):814-8. https://doi. org/10.1016/j.jcrs.2008.01.016

PMid: 18471638

27. LopezHM, MelendezCA, FloresAC, de-Lucio VM. Epidemiological Aspects of Infectious Conjunctivitis; 2011. Available from: https:// www.researchgate.net/publication/221920236_epidemiological_ aspects_of_infectious_conjunctivitis. [Last accessed on $201 \overline{9}$ Nov 15]. https://doi.org/10.5772/27755

28. Crum NF, Barrozo CP, Chapman FA, Ryan MA, Russell KL. An outbreak of conjunctivitis due to a novel un-encapsulated 
Streptococcus pneumonia among military trainees. Clin Infect Dis. 2004;39(8):1148-54. https://doi.org/10.21236/ada433371 PMid: 15486838

29. Buznach N, Dagan R, Greenberg D. Clinical and bacterial characteristics of acute bacterial conjunctivitis in children in the antibiotic resistance era. Pediatr Infect Dis J. 2005;24(9):823-8. https://doi.org/10.1097/01.inf.0000178066.24569.98

PMid: 16148850

30. Costumbrado J, Ng DK, Ghassemzadeh S. Gonococcal conjunctivitis. In: Stat Pearls. Treasure Island, FL: Stat Pearls Publishing; 2021. https://doi.org/10.1016/j.oftale.2020.05.039

31. Borroni D, de Lossada CR. Microbial keratitis: The clinical impact of metagenomic next-generation sequencing (mNGS). Arch Soc Esp Oftalmol. 2020;95(12):621-3.

PMid:33069500
32. Gallon P, Parekh M, Ferrari S, Fasolo A, Ponzin D, Borroni D. Metagenomics in ophthalmology: Hypothesis or real prospective? Biotechnol Rep (Amst). 2019;23:e00355. https:// doi.org/10.1016/j.btre.2019.e00355

PMid:31312608

33. Li Z, Breitwieser FP, Lu J, Jun AS, Asnaghi L, Salzberg SL, et al. Identifying corneal infections in formalin-fixed specimens using next generation sequencing. Invest Ophthalmol Vis Sci. 2018;59(1):280-8. https://doi.org/10.1167/iovs.17-21617 PMid:29340642

34. Kirstahler P, Bjerrum SS, Friis-Møller A, la Cour M, Aarestrup FM, Westh $\mathrm{H}$, et al. Genomics-based identification of microorganisms in human ocular body fluid. Sci Rep. 2018;8(1):4126. https://doi. org/10.1038/s41598-018-22416-4

PMid:29515160 